\title{
Physiological and Biochemical Grounding of Different Nanomaterials Use WhenGrowing Corn Seeds
}

\author{
Polishchuk S. D. ${ }^{1}$, Nazarova, A. A. ${ }^{1}$, Byshov N. V. ${ }^{1}$, Kuznetsov D. V. ${ }^{2}$, Churilov D. G. ${ }^{1} \&$ Churilov G. I. ${ }^{3}$ \\ ${ }^{1}$ Faculty of Chemistry, Agrotechnological University, Ryazan, Russia \\ ${ }^{2}$ University of Science and Technology "MISIS”, Moscow, Russia \\ ${ }^{3}$ Faculty of Organic Chemistry, Medical University, Ryazan, Russia \\ Correspondence: Churilov, G. I., Faculty of Organic Chemistry, Medical University, Ryazan, 390026, Russia. Tel: \\ 7-910-901-3298. E-mail: genchurilov@yandex.ru
}

Received: July 14, 2016

Accepted: August 1, $2016 \quad$ Online Published: November 12, 2016

doi:10.5539/mas.v11n1p195

URL: http://dx.doi.org/10.5539/mas.v11n1p195

\begin{abstract}
We have investigated in labandfield conditions the influence of cornpre-plant treatment with cuprum and cobalt nano particles and humicacids. We have determined the vitaland morpho-physiological parameters of plants and shown that the effective concentrations are within the limit 0.1-1.0 gper hectare norm of seeding rate. We have discovered that nano particlesi ncrease photosynthesis efficiency andactivate oxidation-reduction ferments and parameters of mineral metabolismthat increases fat in grown seeds by $0.63 \%$ as compared with the control.
\end{abstract}

Keywords: corn, seeds, treatment with nanoparticles, growth structure, yield

\section{Introduction}

Growth stimulating bio-drugs are important in determining the level of agricultural crops development and their chemical composition. The long-term investigations of the Center of Nanotechnologies and Nanomaterials for the RF Agro-Industrial Complex (FSBEI HPE RSATU) have shown that bio-drugs based on different nanomaterials can be alternative to modern drugs and activate biochemical and physiological processes in plants to increase the agricultural crops yield and quality(Kutskir, Nazarova, Polishchuk, 2012, pp. 135-152; Nazarova, Polishchuk, Stepanova, Churilov, 2014; Golubeva, Ivanycheva, Nazarova, Polishchuk, Churilov, 2013; Polishchuk, Nazarova, Zheglova, 2013, pp. 9-12).

We studied the influence of different nanoparticles (metals, metals oxides, non-metals, humic acids) on corn growth and development in 2009-2013. The results of our investigations have proved that nanoparticles thanks to their structure, small size, high specific surface and low concentrations create favorable conditions for more intensive growth and development of plants that consist both in their accumulation of vegetative and reproductive mass and biochemical compositionchange (Polishchuk, Nazarova, Kutskir, 2013, p. 104-106; Churilov, Nazarova, Ampleyeva, Polishchuk, Cherkasov, 2010; Nazarova, Polishchuk, Stepanova, Churilov, 2013, pp. 291-295; Churilov, Polishchuk, Nazarova, 2013, pp. 379-385).

The aim of the investigations is determining in lab conditions the optimal concentrations of biologically active cobalt and cuprum nanoparticles and highly dispersed humic acidswhen treating corn seeds and studying the influence of these nanostructures optimal concentrations on growth, development, productivity and chemical composition of corn seeds and plants.

\section{Method}

We had our lab investigations at the Center of Nanotechnologies and Nanomaterials for RF Agro-Industrial Complex at FSBEI HPE RSATU. We used the seeds of the first generation corn hybrid "Obskiy 140". We determined germination energy and lab germination according to GOST 12038-84 "Crops seeds. Methods of determining germination and germination energy" and methods "Determining nanomaterials effect on food and fodder plants in vital and morpho-physiological parameters"developed and tested while working at grant of FCP"Development of RF Nanoindustry Infrastructure for 2008-2011" (Golubeva, Ivanycheva, Nazarova, Polishchuk, Churilov, 2013). We determined germination energy on the third day and lab germination, length and mass of sprouts and roots on the seventh day of the experiment with corn seeds germination. 
We had field tests in 2010-2013 at the agrotechnological station of FSBEI HPE RSATU in township Stenkino, Ryazan district of Ryazan oblastand at the demonstration ground of the Ministry of Agriculture at JSC "Agrotechnology" in township Malinishchi, Pronsk district of Ryazan oblast.

We had the experiment according to field tests methods by Dospekhov (Dospekhov, 1985). The plots' arrangement was systematic and the replication number was four. The plots' area was $56 \mathrm{~m}^{2}$, the harvesting area was $38 \mathrm{~m}^{2}$ and replication was evenly even. It was a one factor experiment. The factor was the pre-plant treatment of corn seeds with different biologically active nanosubstances: cobalt and cuprum nanoparticles and ultrafine humic acids. During the vegetation we determined the following parameters: field germination, leaf-area duration, height and mass of plants in vegetation phases, ferments activity, yield and chemical composition of corn seeds. Table 1 presents the scheme of our tests.

Table 1. The Scheme of Lab and Field Tests

\begin{tabular}{lccc}
\hline$\#$ & Variants & $\begin{array}{c}\text { Concentrations of studied nanosubstances, } \\
\text { g per hectare seeding rate }\end{array}$ \\
\hline \multicolumn{3}{c}{ Lab tests } \\
\hline 1. & Control & - \\
2. & Cobalt nanoparticles (NP Co) & $0.1 ; 0.5 ; 1.0 ; \quad 5.0 ; 10.0$. \\
3. & Cuprum nanoparticles (NP Cu) & $0.1 ; 0.5 ; 1.0 ; 5.0 ; 10.0$. \\
4. & Ultra-fine humic acids (HA) & $0.1 ; 0.5 ; 1.0 ; 5.0 ; 10.0$. \\
\hline \multicolumn{3}{c}{ Field tests } \\
\hline 1. & Control & - \\
2. Cobalt nanoparticles (NP Co) & $0.5 ; 1.0 ; \quad 5.0$ \\
3. & Cuprum nanoparticles (NP Cu) & $0.5 ; 1.0 ; \quad 5.0$ \\
4. & Ultra-fine humic acids (HA) & $0.5 ; 1.0 ; 5.0$ \\
\hline
\end{tabular}

\section{Results}

We have had preliminary lab tests to determine biological activity of cobalt and cuprum nanoparticles. The results have shown that nanoparticles at concentrations of $0.1-10.0 \mathrm{~g}$ per hectare seeding ratestimulate sprouts development. There is a supposition that nanoparticles have the mode of action different from that of microelements. So as compared with cuprum and cobalt nanoparticles we have investigated the same concentrations of humic acids (soil humus component). We have used humic acids being natural growth stimulatorsin an ultra-fine state. Table 2 presents the facts about germination energy and corn seeds germinationinfluenced by biologically active nanomaterials.

Table 2. Vital Parameters of Corn Seeds when Treated with Biologically Active Nanoparticles

\begin{tabular}{|c|c|c|c|c|c|}
\hline Variant & Measures & Variant & Meast & Variant & Mea \\
\hline \multicolumn{6}{|c|}{ Germination energy, \% } \\
\hline Control & $88.4 \pm 2.6$ & ontrol & $.4 \pm 2.6$ & ontrol & $3.4 \pm 2.6$ \\
\hline NP & & & & 01 & \\
\hline NP-C & & & & 5 & \\
\hline NP & & & & & \\
\hline NP & & & & & \\
\hline NP-Co & $89.3 \pm 2.0$ & HA & 91. & 0.0 & 2.1 \\
\hline \multicolumn{6}{|c|}{ Lab germination, $\%$} \\
\hline Contrc & $96.6 \pm 2.4$ & & .4 & Con & $96.6 \pm 2.4$ \\
\hline NP- & $98.0 \pm 2.5$ & & 9 & NP- & $100.0 \pm 0.2$ \\
\hline NP-Co 0. & $98.4 \pm 1.7$ & $\mathrm{HA}$ & $94.2 \pm 2.1$ & $\mathrm{NP}-\mathrm{Cu} 0.5$ & $98.6 \pm 2.5$ \\
\hline NP-C & $97.2 \pm 1.9$ & & $92.4 \pm 2.0$ & NP-Cu 1.0 & $98.2 \pm 2.6$ \\
\hline & $96.0 \pm$ & & $95.2 \pm 2.6$ & NP-Cu 5.0 & $97.1 \pm 2.7$ \\
\hline NP-Co 10.0 & $96.0 \pm 1.8$ & HA - 10.0 & $94.2 \pm 2.4$ & $\mathrm{NP}-\mathrm{Cu} 10.0$ & $96.8 \pm 2.4$ \\
\hline
\end{tabular}

The use of cobalt and cuprum nanoparticles and ultra-fine humic acids in lab tests has led to the increase of corn 
seeds germination energy. Cobalt and cuprum nanoparticles in all concentrations have had the positive result andthe germination energy on the third day of the experiment has on the average been $4.0 \%$ higher than that of the control. We have observed the maximum $3.4 \%$ increase of germination energy as compared with the control under the influence of humic acidsonly at $0.1 \mathrm{~g}$ concentration of the active agent. Biologically active nanoparticles of cobalt and cuprum and ultra-fine humic acids have also increased seeds germination. When using cobalt nanoparticles and humic acids the lab germination has exceeded the control one on the average by $1.5 \%-2 \%$. This parameter value has been $100 \%$ when using $0.1 \mathrm{~g}$ cuprum nanoparticles and that proves the high stimulation of growth processes. Table 3 presentsthe facts about the corn sprouts and roots length when treated with nanomaterials on the $7^{\text {th }}$ day of the experiment.

Table 3. Morphological Parameters of Corn Seeds when Treated with Biologically Active Nanoparticles

\begin{tabular}{|c|c|c|c|c|c|}
\hline Variant & $\begin{array}{l}\text { Length of plantlet's } \\
\text { aerial portion, } \mathrm{mm}\end{array}$ & Variant & $\begin{array}{l}\text { Length of plantlet's } \\
\text { aerial portion, } \mathrm{mm}\end{array}$ & Variant & $\begin{array}{l}\text { Length of plantlet's } \\
\text { aerial portion, } \mathrm{mm}\end{array}$ \\
\hline Control & 16.03 & Control & 16.03 & Control & 16.03 \\
\hline NP-Co & 16.93 & HA & - $\quad 16.84$ & $\mathrm{NP}-\mathrm{Cu}$ & 17.64 \\
\hline 0.1 & & 0.1 & & 0.1 & \\
\hline NP-Co & 17.50 & HA & - $\quad 17.18$ & $\mathrm{NP}-\mathrm{Cu}$ & 17.61 \\
\hline 0.5 & & 0.5 & & 0.5 & \\
\hline NP-Co & 16.83 & HA & $\begin{array}{l}-\quad 16.27\end{array}$ & $\mathrm{NP}-\mathrm{Cu}$ & 17.45 \\
\hline 1.0 & & 1.0 & & 1.0 & \\
\hline NP-Co & 17.43 & HA & $\begin{array}{l}-\quad 16.52 \\
\end{array}$ & $\mathrm{NP}-\mathrm{Cu}$ & 15.93 \\
\hline 5.0 & & 5.0 & & 5.0 & \\
\hline NP-Co & 16.07 & HA & - $\quad 16.43$ & $\mathrm{NP}-\mathrm{Cu}$ & 15.71 \\
\hline 10.0 & & 10.0 & & 10.0 & \\
\hline Variant & $\begin{array}{l}\text { Length of plantlet's } \\
\text { underground part, mm }\end{array}$ & Variant & $\begin{array}{l}\text { Length of plantlet's } \\
\text { underground part, mm }\end{array}$ & Variant & $\begin{array}{l}\text { Length of plantlet's } \\
\text { underground part, mm }\end{array}$ \\
\hline Control & 83.2 & Control & 83.2 & Control & 83.2 \\
\hline NP-Co & 84.1 & HA & 85.6 & $\mathrm{NP}-\mathrm{Cu}$ & 86.4 \\
\hline 0.1 & & 0.1 & & 0.1 & \\
\hline NP-Co & 85.5 & HA & - 83.4 & $\mathrm{NP}-\mathrm{Cu}$ & 90.1 \\
\hline 0.5 & & 0.5 & & 0.5 & \\
\hline NP-Co & 84.5 & HA & - $\quad 82.4$ & $\mathrm{NP}-\mathrm{Cu}$ & 89.5 \\
\hline 1.0 & & 1.0 & & 1.0 & \\
\hline NP-Co & 83.1 & HA & - $\quad 82.8$ & $\mathrm{NP}-\mathrm{Cu}$ & 81.2 \\
\hline 5.0 & & 5.0 & & 5.0 & \\
\hline NP-Co & 80.5 & HA & - $\quad 80.4$ & $\mathrm{NP}-\mathrm{Cu}$ & 84.2 \\
\hline 10.0 & & 10.0 & & 10.0 & \\
\hline
\end{tabular}

The length of the corn plantlet's aerial portion when treated with cobalt nanoparticles and humic acids has exceeded the control maximum by $9.1 \%-7.1 \%$ correspondingly at concentration of $0.5 \mathrm{~g}$. For cuprum nanoparticles the maximum result has been at active agent concentration of $0.1 \mathrm{~g}$. The positive difference has been $10 \%$ as compared with the control. The biologically active substances have improved the plantlet's underground part growth as well. So the roots' length in a case with $0.5 \mathrm{~g}$ cobalt nanoparticles treatment has exceeded the control one by $3 \%$ and in a case with cuprum nanoparticles by $8 \%$. Ultra-fine humic acids have not changed the root length.

We have also determined the corn sprouts and roots massin the lab tests. It deserves to be mentioned that the plantlets' root massin all experimental variants has several times exceeded the control. The maximum mass of the corn plantlets treated with cobalt nanoparticles has 2.5 times exceeded the control, in a case with ultrafine humic acids it has been 3 times more and with cuprum nanoparticles 4 times more. The experiment data prove that biologically active nanosubstances promote the plantlets' roots development and this is a necessary condition for their survival at next vegetation stages.

The lab tests have proved that cobalt, cuprum and ultra-fine humic acids nanoparticles have high biological activity. That is why we have chosen for field tests the active agents concentrations having maximum efficiency and these are $0.1 \mathrm{~g}, 0.5 \mathrm{~g}$ and $1.0 \mathrm{~g}$ per hectare seeding rate. 
At the next stage we had tests to study biological activity of nanomaterials with corn in field conditions. The used corn hybrid "Obskiy 140" is an early season one and its vegetation period in optimal climate is 90-100 days. Taking into account the climate of Ryazan oblast this corn hybrid needs up to 120 days. From the facts presented in Table 4 the corn vegetation period has been 121 days and that is normal for Ryazan oblast conditions.

Table 4. Corn Vegetation Periods and Their Dates (2013 data)

\begin{tabular}{|c|c|c|c|c|c|c|c|c|c|}
\hline $\begin{array}{l}\text { Seeding } \\
\text { time }\end{array}$ & Germination & $\begin{array}{l}\text { Third-f } \\
\text { ourth } \\
\text { leaves }\end{array}$ & $\begin{array}{l}\text { Stalk } \\
\text { extension }\end{array}$ & Tasselling & Blossoming & $\begin{array}{l}\text { Milky } \\
\text { stage }\end{array}$ & $\begin{array}{l}\text { Gold } \\
\text { ripeness }\end{array}$ & $\begin{array}{l}\text { Complete } \\
\text { ripeness }\end{array}$ & $\begin{array}{l}\text { Germin } \\
\text { ation } \\
\text { ripeness }\end{array}$ \\
\hline $\begin{array}{l}17.05 . \\
2013\end{array}$ & $\begin{array}{l}27.05 \\
10 \text { days }\end{array}$ & $\begin{array}{l}8.06 . \\
12 \\
\text { days }\end{array}$ & $\begin{array}{l}18.06 . \\
10 \text { days }\end{array}$ & $\begin{array}{l}7.07 . \\
29 \text { days }\end{array}$ & $\begin{array}{l}22.07 . \\
15 \text { days }\end{array}$ & $\begin{array}{l}16.08 \\
25 \\
\text { days }\end{array}$ & $\begin{array}{l}29.08 . \\
13 \text { days }\end{array}$ & $\begin{array}{l}15.09 . \\
17 \text { days }\end{array}$ & $\begin{array}{l}121 \\
\text { days }\end{array}$ \\
\hline
\end{tabular}

The sum of active temperatures for this early season hybrid has on the average been 2000 grades Celsius. Judging by the vegetation period of 121 day the sum of active temperatures from middle May till middle September has been 2001.6 degrees and that is enough for grain ripeness. The normal germination of this corn hybridis from $80 \%$ to $95 \%$. Table 5 shows that germination of the control seeds is $82 \%$ that is normal for this hybrid.

Table 5. Corn Seeds Field Germination

\begin{tabular}{llllll}
\hline Variant & Field germination, \% & Variant & Field germination, \% & Variant & Field germination, \% \\
\hline Control & $82.0 \pm 3.1$ & Control & $82.0 \pm 3.1$ & Control & $82.0 \pm 3.1$ \\
NP-Co 0.1 & $92.0 \pm 2.9$ & HA - 0.1 & $91.4 \pm 2.5$ & NP-Cu 0.1 & $93.2 \pm 2.7$ \\
NP-Co 0.5 & $92.6 \pm 3.0$ & HA - 0.5 & $92.5 \pm 3.0$ & NP-Cu 0.5 & $94.6 \pm 2.5$ \\
NP-Co 1.0 & $91.4 \pm 2.6$ & HA - 1.0 & $92.8 \pm 2.7$ & NP-Cu 1.0 & $93.6 \pm 2.9$ \\
\hline
\end{tabular}

Field germination of the experimental seeds is considerably higher than that of the control. When corn seeds pre-plant treatment with cobalt nanoparticles the field germination in all variants has been $9.4 \%-10.6 \%$ higher than that of the control. When humic acids treatment it has been $10.8 \%$ and when cuprum treatment it has been $12.6 \%$ higher than that of the control.The increase of field germination causes the increase of plants at the plot and then promotes the yield.

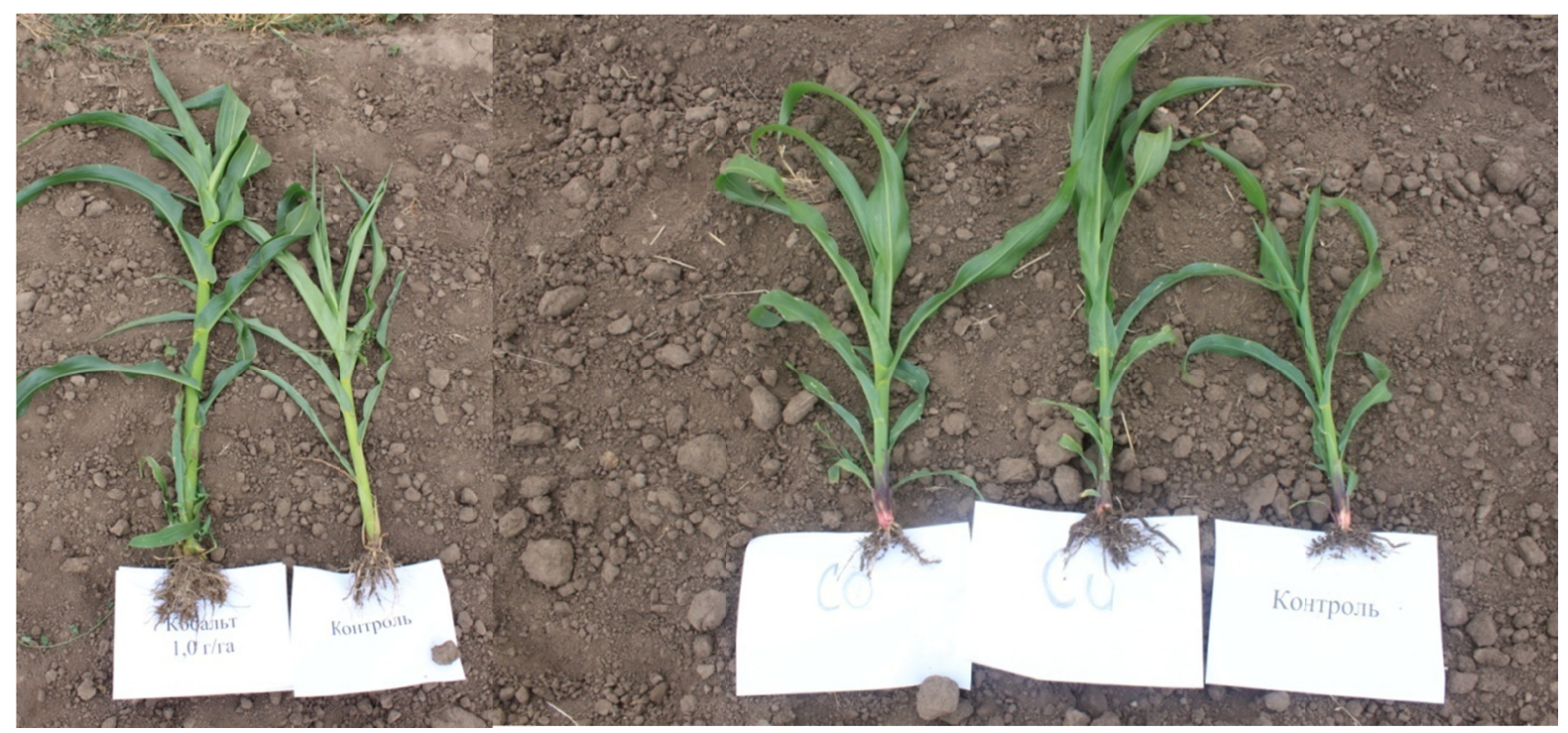

Figure 1. The control and experiment corn with 7-9 leaves 
The stage of 3-4 leaves is the main one in vegetation period because plants are most sensitive to weeding. The higher the plants are at this period the more chances for good yield you have. Table 6 shows that the use of biologically active cobalt, cuprum and ultra-fine humic acids nanoparticles has caused the increase of the plants height. So when using $0.5 \mathrm{~g}$ humic acids the plants' height has been on average $8.1 \%$ higher than that of the control, when cobalt nanoparticles by $20.2 \%$ and when cuprum nanoparticles by $13.9 \%, 23.7 \%$ and $17.8 \%$ correspondingly to concentrations of $0.1 \mathrm{~g}, 0.5 \mathrm{~g}$ and $1.0 \mathrm{~g}$.

The use of cobalt nanoparticles has promoted the growth while corn blossoming. At concentration of $0.1 \mathrm{gthe}$ plants' height has been $102.02 \mathrm{~cm}$ and that is $19.7 \%$ higher than that of the control. The increase of concentration has caused the height increase up to the difference of $+22.15 \%$. Ultra-fine humic acidshave also stimulated the plants' development when blossoming. The height of plants being treated with humic acids has been on average $23.69 \%$ higher than the control one. The corn height being treated with $0.1 \mathrm{~g}$ cuprum nanoparticles has been $15 \%$ higher than the control one and $36.5 \%$ higher at concentration of $1.0 \mathrm{~g}$.

The analysis of the control and experiment plants mass has shown (Table 6) that all the nanomaterials being studied have increased this parameter.

Table 6. Height and Mass of Corn Plants at the Stage of 3-4 Leaves

\begin{tabular}{|c|c|c|c|c|c|}
\hline \multicolumn{6}{|c|}{ Plants height } \\
\hline Variant & Plantsheight, $\mathrm{cm}$ & Variant & Plantsheight, $\mathrm{cm}$ & Variant & Plantsheight, $\mathrm{cm}$ \\
\hline Control & 46.0 & Control & 46.0 & Control & 46.0 \\
\hline NP-Co 0.1 & 48.7 & HA - 0.1 & 49.5 & NP-Cu 0.1 & 52.4 \\
\hline NP-Co 0.5 & 55.3 & HA - 0.5 & 51.3 & NP-Cu 0.5 & 56.9 \\
\hline NP-Co 1.0 & 52.6 & HA - 1.0 & 48.4 & NP-Cu 1.0 & 54.2 \\
\hline \multicolumn{6}{|l|}{ Plants mass } \\
\hline Variant & 1 plant mass, $g$ & Variant & 1 plant mass, $\mathrm{g}$ & Variant & 1 plant mass, $g$ \\
\hline Control & 154 & Control & 154 & Control & 154 \\
\hline NP-Co 0.1 & 165 & HA - 0.1 & 160 & NP-Cu 0.1 & 169 \\
\hline NP-Co 0.5 & 178 & HA - 0.5 & 164 & NP-Cu 0.5 & 182 \\
\hline NP-Co 1.0 & 163 & HA - 1.0 & 169 & NP-Cu 1.0 & 178 \\
\hline
\end{tabular}

Cobalt nanoparticles have increased the plants mass at concentrations of 0.5 gand 1.0 gby $11.8 \%$ and $6 \%$ correspondingly. The corn plants mass when treated with humic acids has been on average $21 \%$ lower than the control in all experiment variants but with concentration increase the difference has declined. Cuprum nanoparticles have stimulated the corn mass growth. At concentration of 0.1 gthe mass has exceeded the control one by $3 \%$, at concentration of 0.5 gby $9 \%$ and at concentration of $1.0 \mathrm{~g}$ by $6 \%$.

Table 7. Corn Leaf Area and Photosynthesis Efficiency

\begin{tabular}{|c|c|c|c|c|c|}
\hline $\begin{array}{l}\text { Variant } \\
\text { Corn }\end{array}$ & Leaf area, $\mathrm{cm}^{2}$ & Variant & Leaf area, $\mathrm{cm}^{2}$ & Variant & Leaf area, $\mathrm{cm}^{2}$ \\
\hline Control & $670.4 \pm 3.56$ & Control & $670.4 \pm 3.56$ & Control & $670.4 \pm 3.56$ \\
\hline NP-Co 0.1 & $720.9 \pm 4.13$ & HA - 0.1 & $707.8 \pm 3.78$ & NP-Cu 0.1 & $732.9 \pm 4.21$ \\
\hline NP-Co 0.5 & $735.6 \pm 4.81$ & HA - 0.5 & $723.7 \pm 4.02$ & NP-Cu 0.5 & $720.5 \pm 4.57$ \\
\hline NP-Co 1.0 & $700.9 \pm 4.61$ & HA - 1.0 & $698.7 \pm 3.99$ & NP-Cu 1.0 & $717.9 \pm 4.59$ \\
\hline Variant & $\begin{array}{l}\text { Photosynthesis } \\
\text { intensity,g } / \mathrm{dm}^{2}\end{array}$ & Variant & $\begin{array}{l}\text { Photosynthesis } \\
\text { intensity, } \mathrm{g} / \mathrm{dm}^{2}\end{array}$ & Variant & $\begin{array}{l}\text { Photosynthesis } \\
\text { intensity, } \mathrm{g} / \mathrm{dm}^{2}\end{array}$ \\
\hline Control & $50.09 \pm 3.41$ & Control & $50.09 \pm 3.41$ & Control & $50.09 \pm 3.41$ \\
\hline NP-Co 0.1 & $54.65 \pm 3.76$ & HA - 0.1 & $56.83 \pm 3.28$ & NP-Cu 0.1 & $57.83 \pm 3.11$ \\
\hline NP-Co 0.5 & $56.72 \pm 3.61$ & HA - 0.5 & $53.53 \pm 2.55$ & NP-Cu 0.5 & $54.72 \pm 3.50$ \\
\hline NP-Co 1.0 & $53.40 \pm 3.98$ & HA - 1.0 & $52.75 \pm 3.86$ & NP-Cu 1.0 & $51.34 \pm 3.21$ \\
\hline
\end{tabular}

The corn leaves area when seeds treated with $0.1 \mathrm{~g}$ cobalt nanoparticles has exceeded the control one by $7.5 \%$ and with $0.5 \mathrm{~g}$ cobalt nanoparticles by $9.7 \%$. This variant has had photosynthesis intensity higher than that of the control one.In a case with $0.1 \mathrm{~g}$ cobalt nanoparticles it has been $8.9 \%$ higher and $0.5 \mathrm{~g}$ cobalt nanoparticles $13.2 \%$ higher. 
We have also determined peroxydase, superoxide dismutase (Table 8) and catalase (Table 9) activity during corn vegetation process.

Table 8. Peroxydase Activity (inopt.dens. units / g raw material $\bullet$ sec) and Superoxide DismutaseActivity (in act.stand. units / g raw material) in Corn Roots and Leaves Influenced by Different Nanoparticles

\begin{tabular}{|c|c|c|c|c|c|c|c|c|}
\hline \multirow[t]{3}{*}{ Variant } & \multicolumn{4}{|c|}{ PEROXYDASE } & \multicolumn{4}{|c|}{ SUPEROXIDE DISMUTASE } \\
\hline & Roots & & Leaves & & Roots & & Leaves & \\
\hline & $\begin{array}{l}\text { Absolute } \\
\text { value }\end{array}$ & $\begin{array}{l}\% \text { to } \\
\text { the } \\
\text { control }\end{array}$ & $\begin{array}{l}\text { Absolute } \\
\text { value }\end{array}$ & $\begin{array}{l}\% \text { to the } \\
\text { control }\end{array}$ & $\begin{array}{l}\text { Absolute } \\
\text { value }\end{array}$ & $\begin{array}{l}\% \text { to } \\
\text { the } \\
\text { control }\end{array}$ & $\begin{array}{l}\text { Absolute } \\
\text { value }\end{array}$ & $\begin{array}{l}\% \text { to the } \\
\text { control }\end{array}$ \\
\hline Control & $6.04 \pm 0.56$ & - & $3.48 \pm 0.12$ & & $47.31 \pm 1.43$ & - & $109.06 \pm 1.23$ & - \\
\hline NP-Co 0.1 & $7.38 \pm 0.47$ & +22.2 & $3.66 \pm 0.13$ & +5.2 & $54.51 \pm 1.56$ & +15.2 & $110.47 \pm 1.53$ & +1.3 \\
\hline NP-Co 0.5 & $7.50 \pm 0.59$ & +24.1 & $4.10 \pm 0.21$ & +17.8 & $46.45 \pm 1.34$ & -1.9 & 108. $1 \pm 1.31$ & -0.9 \\
\hline NP-Co 1.0 & $7.82 \pm 0.71$ & +29.5 & $4.41 \pm 0.17$ & +26.7 & $49.24 \pm 1.76$ & +4.1 & $98.23 \pm 1.37$ & -9.9 \\
\hline HA - 0.1 & $6.94 \pm 0.51$ & +14.9 & $3.56 \pm 0.18$ & +2.3 & $53.84 \pm 1.51$ & +13.8 & $111.46 \pm 1.04$ & +2.2 \\
\hline HA - 0.5 & $7.04 \pm 0.49$ & +16.5 & $3.67 \pm 0.14$ & +5.4 & $49.08 \pm 1.58$ & +3.7 & $109.88 \pm 1.29$ & +0.8 \\
\hline HA - 1.0 & $7.12 \pm 0.61$ & +17.9 & $4.01 \pm 0.24$ & +15.2 & $44.62 \pm 1.74$ & +9.4 & $102.4 \pm 1.79$ & -6.1 \\
\hline NP-Cu 0.1 & $6.82 \pm 0.64$ & +12.9 & $3.51 \pm 0.21$ & +0.8 & $51.2 \pm 1.63$ & +8.2 & $118.94 \pm 1.52$ & +9.1 \\
\hline NP-Cu 0.5 & $7.54 \pm 0.61$ & +24.8 & $3.78 \pm 0.19$ & +8.6 & $52.67 \pm 1.58$ & +11.3 & $113.5 \pm 1.86$ & +4.1 \\
\hline $\mathrm{NP}-\mathrm{Cu} 1.0$ & $7.61 \pm 0.53$ & +26.0 & $4.29 \pm 0.12$ & +23.3 & $49.82 \pm 1.71$ & +5.3 & $102.56 \pm 1.94$ & -5.9 \\
\hline
\end{tabular}

Peroxydase activity in corn roots treated with cobalt nanoparticles at maximum concentration has exceeded the control by $29.5 \%$. And superoxide dismutase activity in roots has been $9.9 \%$ lower than that of the control. Humic acids have increased peroxydase activity in corn roots on average by $16 \%$. This ferment activity in leaves has been higher than the control by $2.3 \%$ at concentration of $0.1 \mathrm{~g}$ and by $15 \%$ at concentration of $1.0 \mathrm{~g}$. Superoxide dismutase activity has not differed considerably from that of the control.

Cuprum nanoparticles in all doses have also increased peroxydase activity in roots of the experiment plants by up to $26 \%$ as compared with the control. At concentrations of $0.1 \mathrm{~g}$ and 0.5 gperoxydase activity in leaves has been $0.8 \%$ and $8.6 \%$ higher than the control correspondingly. Superoxide dismutase activity at concentration of $0.1 \mathrm{~g}$ has been $8.2 \%$ higher in roots than those of the control and $9.1 \%$ higher in leaves. With the increase of the active agent concentration superoxide dismutase activity has decreased.

Table 9. Catalase Activity in Corn Plants and Roots

\begin{tabular}{lllll}
\hline Variant & $\begin{array}{l}\text { Corn } \\
\text { Roots } \\
\text { Absolute value }\end{array}$ & \% to the control & $\begin{array}{l}\text { Leaves } \\
\text { Absolute value }\end{array}$ & \% to the control \\
\hline Control & 24.97 & - & 46.40 & - \\
NP-Co 0.1 & 25.63 & +2.6 & 48.76 & +5.1 \\
NP-Co 0.5 & 26.41 & +5.8 & 46.52 & +0.2 \\
NP-Co 1.0 & 27.01 & +8.1 & 44.19 & -4.7 \\
HA - 0.1 & 24.89 & -0.3 & 47.03 & +1.3 \\
HA - 0.5 & 25.71 & +2.9 & 45.81 & -1.3 \\
HA - 1.0 & 26.84 & +7.5 & 45.26 & -2.5 \\
NP-Cu 0.1 & 25.47 & +2.0 & 47.89 & +3.2 \\
NP-Cu 0.5 & 25.98 & +4.0 & 44.56 & -3.9 \\
NP-Cu 1.0 & 27.65 & +10.7 & 42.16 & -9.1 \\
\hline
\end{tabular}

Catalase activity in corn is within acceptance limits. When using cobalt nanoparticles catalase activity in roots exceeds the control by $2.6-8.1 \%$. We have noticed this ferment activity true increase in corn leaves only at concentration of 0.1 gby $5.1 \%$ as compared with the control. Catalase activity increase shows large amount of metabolic hydrogen peroxide but the experiment plants have not got any considerable activity increase. At maximum concentrations of humic acids and cuprum nanoparticles $(1.0 \mathrm{~g})$ catalase activity in corn roots exceeded the control one by $7.5 \%$ and $10.7 \%$ correspondingly. Catalase activity in the herbage has been lower 
than the control at cuprum nanoparticles concentration of $1.0 \mathrm{~g}$ by $9.1 \%$.

Table 10 shows that corn treated with cuprum nanoparticles have considerable $61 \%$ increase of its amount in seeds and flowers as compared with the control but the leaves practically do not have any changes.

Table 10. Biogenic Metals in Corn

\begin{tabular}{lllll}
\hline Object & Parts of plants & $\mathrm{Cu}, \mathrm{mg} / \mathrm{kg}$ & $\mathrm{Co}, \mathrm{mg} / \mathrm{kg}$ & $\mathrm{Fe}, \mathrm{mg} / \mathrm{kg}$ \\
\hline CornSeeds & Seeds treated before storage & $1.9561 \pm 0.4144$ & $46.413 \pm 0.0065$ & $8.0298 \pm 3.3457$ \\
Control Corn & Seeds + Flowers & $1.6361 \pm 0.0606$ & $93.047 \pm 0.0172$ & $21.282 \pm 1.4322$ \\
& Leaves & $10.570 \pm 0.7528$ & $266.84 \pm 0.0232$ & $80.049 \pm 5.5013$ \\
& Root & $8.8142 \pm 0.3624$ & $483.89 \pm 0.0176$ & $379.78 \pm 2.5921$ \\
Corn & Seeds + Flowers & $2.6485 \pm 0.4232$ & $92.733 \pm 0.0113$ & $32.142 \pm 4.2235$ \\
treated withCu & Leaves & $10.864 \pm 0.3538$ & $294.96 \pm 0.0121$ & $64.967 \pm 1.3869$ \\
(NP - Cu 0.1) & Root & - & - & - \\
Corn & Seeds + Flowers & $1.1778 \pm 0.07778$ & $51.861 \pm 0.0024$ & $15.724 \pm 2.1908$ \\
treated withCo & Leaves & $23.210 \pm 0.1383$ & $798.35 \pm 0.0173$ & $121.06 \pm 2.7072$ \\
$(\mathrm{NP}-\mathrm{Co} 0.5)$ & Root & - & - & - \\
\hline
\end{tabular}

Seeds treated with cuprum nanoparticles do not have any changes of cobalt. Seeds treated with cuprum nanoparticles have $51 \%$ more ferrum in seeds and flowers than those of the control and it can be connected with biological antagonism of ferrum and cuprum in biochemical processes of plants. The leaves of experiment plants have $18.8 \%$ less ferrum. Corn treatment with cobalt nanoparticles has caused $119 \%$ cuprum increase in leaves in comparison with the control ones. The leaves have also had $200 \%$ more cobalt than the control variant. But flowers and seeds have got $45 \%$ less cobalt. Leaves are the place where basic processes connected with energy metabolism take place so cobalt increase has strengthened the biochemical processes. The leaves when the seeds treated with cobalt nanoparticles have got $26 \%$ less ferrum than those of the control.

We have determined the yield (Table 11) and chemical composition of corn seeds (Table 12) at the end of vegetation.

Table 11. Corn Yield

\begin{tabular}{llllll}
\hline Variant & Yield, dt/he & Variant & Yield, dt/he & Variant & Yield, dt/he \\
\hline Control & 18.2 & Control & 18.2 & Control & 18.2 \\
NP-Co 0.1 & 20.4 & HA - 0.1 & 19.6 & NP-Cu 0.1 & 23.8 \\
NP-Co 0.5 & 24.8 & HA - 0.5 & 20.9 & NP-Cu 0.5 & 22.8 \\
NP-Co 1.0 & 21.9 & HA - 1.0 & 20.5 & NP-Cu 1.0 & 21.7 \\
\hline
\end{tabular}

Corn yield in a case with cobalt nanoparticles has exceeded the control on average by $23.3 \%$, with ultra-fine humic acids by $11.6 \%$ and with cuprum nanoparticles by $26.3 \%$.

Table 12. Chemical Composition of Corn Seeds

\begin{tabular}{|c|c|c|c|c|c|c|c|c|c|c|}
\hline \multirow[b]{2}{*}{ Variant } & \multicolumn{2}{|l|}{ Fat } & \multicolumn{2}{|c|}{ Total ash } & \multicolumn{2}{|c|}{ Crude protein } & \multicolumn{2}{|c|}{ Moisture } & \multicolumn{2}{|c|}{ Dry matter } \\
\hline & $\%$ & $\begin{array}{l}\text { Ratio } \\
\text { tothe } \\
\text { control }\end{array}$ & $\%$ & $\begin{array}{l}\text { Ratio } \\
\text { tothe } \\
\text { control }\end{array}$ & $\%$ & $\begin{array}{l}\text { Ratio } \\
\text { tothe } \\
\text { control }\end{array}$ & $\%$ & $\begin{array}{l}\text { Ratio } \\
\text { tothe } \\
\text { control }\end{array}$ & $\%$ & $\begin{array}{l}\text { Ratio } \\
\text { tothe } \\
\text { control }\end{array}$ \\
\hline Control & 4.49 & - & 1.30 & - & 11.01 & - & 11.5 & - & 88.5 & - \\
\hline $\begin{array}{l}\mathrm{NP}-\mathrm{Cu} \\
0.1\end{array}$ & 4.92 & +0.43 & 1.25 & -0.05 & 11.40 & +0.39 & 9.8 & -1.7 & 90.2 & +1.7 \\
\hline $\begin{array}{l}\mathrm{NP}-\mathrm{Cu} \\
0.5\end{array}$ & 4.69 & +0.20 & 1.34 & +0.04 & 11.25 & +0.24 & 9.7 & -1.8 & 90.3 & +1.8 \\
\hline $\begin{array}{l}\mathrm{NP}-\mathrm{Cu} \\
1.0\end{array}$ & 4.78 & +0.29 & 1.45 & +0.15 & 11.36 & +0.35 & 10.5 & -1.0 & 89.5 & +1.0 \\
\hline
\end{tabular}




\begin{tabular}{llllllllllll}
\hline HA & - & 4.87 & +0.38 & 1.26 & -0.04 & 11.26 & +0.25 & 10.3 & -1.2 & 89.7 & +1.2 \\
0.1 & & & & & & & & & & & \\
HA & - & 5.02 & +0.53 & 1.32 & +0.02 & 11.12 & +0.11 & 9.8 & -1.7 & 91.2 & +1.7 \\
0.5 & - & & & & & & & & & & \\
HA & 4.98 & +0.49 & 1.28 & -0.02 & 11.07 & +0.06 & 10.5 & -1.0 & 89.5 & +1.0 \\
$\begin{array}{l}1.0 \\
\text { NP-Co }\end{array}$ & 5.10 & +0.61 & 1.46 & +0.16 & 11.02 & +0.01 & 10.0 & -1.5 & 90.0 & +1.5 \\
$\begin{array}{l}0.1 \\
\text { NP-Co }\end{array}$ & 5.12 & +0.63 & 1.50 & +0.20 & 11.05 & +0.04 & 10.4 & -1.1 & 89.6 & +1.1 \\
$\begin{array}{l}0.5 \\
\text { NP-Co }\end{array}$ & 4.88 & +0.39 & 1.47 & +0.17 & 11.33 & +0.32 & 10.5 & -1.0 & 89.5 & +1.0 \\
1.0 & & & & & & & & & \\
\hline
\end{tabular}

The use of cuprum nanoparticles at concentration of 0.1 ghascaused $0.43 \%$ fat increase as compared with the control. Cobalt nanoparticles at the same concentration have got $0.63 \%$ fat increase in comparison with the control plants.

Total ash characterizes seeds mineral metabolism. Cuprum nanoparticles at concentration of 0.1 ghave caused total ash decline in seeds by $0.05 \%$ but with the increase of concentration total ash has increased up to the positive difference with the control $(+0.29 \%)$. Cobalt nanoparticles at concentration of 0.5 ghave caused total ash increase in seeds by $0.2 \%$ in comparison with the control. This can prove the more intensive absorption of mineral substances by the plant. And the dry matter of the experiment plants in all variants has been higher than that of the control.

The lab tests with corn seeds and sprouts have proved biological activity of nano materials being studied, i.e. cobaltand cuprum nano particles and ultra fine humicacids. The study of vital, morphological and physiological parameters has shown that the most efficient concentrations are in the range of 0.1-1.0 g per hectare seeding rate.

The field tests to study the influence of nanomaterials on corn in vegetation have shown that nanoparticles increase field germination of seeds, growth and development of plants, leaf area and photosynthesis efficiency; strengthen redox enzyme activity and mineral metabolism parameters. Nanoparticles increase the yield of corn seeds and change their chemical composition as for fat, total ash and protein increase.

On the whole, as a result of lab and field tests we can say that cuprum nanoparticles at concentration of $0.1 \mathrm{~g}$ per hectare seeding rate are most efficient to increase corn yield and quality.

\section{References}

Churilov, G. I., Nazarova, A. A., Ampleyeva, L. E., Polishchuk, S. D., \& Cherkasov, O. V. (2010). Biological Effect of Nano-Dimensioned Metals Influence on Different Groups of Plants. Monograph. Ryazan, p. 148.

Churilov, G. I., Polishchuk, S. D., \& Chau, N. H. (2012). Ecological and Biological Effects of Nanocrystalline Metals. 6th International Workshop on Advanced Materials Science and Nanotechnology and 6th Korea-Vietnam Joint Symposium on Photonics and Applications. Programme and Abstracts. Vietnam., p. 175.

Churilov, G. I., Polishchuk, S. D., Nazarova, A. A. Cuprum and Cobalt Nano-Particles Influence on Bull-Calves' Growth and Development. Journal of Materials Science and Engineering, 3, 379-385.

Dospekhov, B. A. (1985). Field Experiment Technique. M: Agropromizdat, 351.

Golubeva, N. I, Ivanycheva, Y. N., Nazarova, A. A., Polishchuk, S. D., \& Churilov, G. I. (2013). Determining Nano-Materials Influence on Food and Fodder Plants According to Vital and Morpho-Physiologic Indexes. Guideline for Students, Aspirants and Researchers. Ryazan: RSATU Publishing House, 54.

Kutskir, M. V., Nazarova, A. A., \& Polishchuk, S. D. (2012). Different Cuprum Fertilizers Influence on Physiologic, Bio-Chemical and Productive Indexes of Spring Wheat. Ecology and Ecosystem Exploitation, 3. Selects of International Symposium on Fundamental and Applied Problems of Science. - M.: RAS, 135-152.

Nazarova, A. A., Polishchuk, S. D., Stepanova, I. A., \& Churilov, G. I. (2013). Nguyen Hoai Chau. Biosafety of the application of biogenic nanometal powders in husbandry. The main 4th International Workshop on Nanotechnology and Application - IWNA. - Vung Tau, Vietnam, 14-16, 291-295. 
Nazarova, A. A., Polishchuk, S. D., Stepanova, I. A., \& Churilov, G. I. (2014).Hoai Chau Nguyen, Quoc Buu Ngo. Biosafety of the application of biogenic nanometal powders in husbandry. J. Advances in Natural Sciences: Nanoscience and Nanotechnology, 5(1).

Polishchuk, S. D., Nazarova, A. A., \& Zheglova, T. V. (2013). Developing Growth Stimulators for Agricultural Plants on the Basis of Highly-Dispersed Humic Acids. // Catalogue: Nano-Technological Developments of Agrarian Universities. - M.: FSBSI "Rosinformagrotech", 9-12.

Polishchuk, S. D., Nazarova, A. A., \& Kutskir, M. V. (2013). Sunflower Yield and Bio-Chemical Composition when Treated with Cuprum Nano-Particles. RSATU Reporter, 2(18), 104-106.

\section{Copyrights}

Copyright for this article is retained by the author(s), with first publication rights granted to the journal.

This is an open-access article distributed under the terms and conditions of the Creative Commons Attribution license (http://creativecommons.org/licenses/by/4.0/). 